\title{
Health care workers, mandatory influenza vaccination policies and the law
}

\author{
Vanessa Gruben LLB LLM, Reed A. Siemieniuk MD, Allison McGeer MSc MD
}

Competing interests: Allison McGeer has received funding from Sanofi-Pasteur, Novartis and GlaxoSmithKline for influenza vaccine-related research activities. No other competing interests were declared.

This article has been peer reviewed.

Correspondence to: Allison McGeer, amcgeer@mtsinai.on.ca

CMAJ 2014. DOI:10.1503 /cmaj.140035
$\mathrm{O}$ ver the last few years, there has been increasing discussion about the importance of influenza vaccination for health care workers. There is consensus that all health care workers should receive the influenza vaccine annually, ${ }^{1-4}$ but the actual vaccination rates in this group remain below $50 \% .^{5,6}$ In response to this low rate and the evidence that vaccination of health care workers is associated with improved patient outcomes, an increasing number of expert and professional groups recommend that annual influenza vaccination be a condition of service in the health care industry. 7.8

Although much has been written about the evidence that the vaccination of health care workers against influenza improves patient outcomes $\mathrm{s}^{3,4,7}$ and about the ethics of mandating vaccination, ${ }^{9,10}$ there is much less published information on aspects of implementation of such policies.

We provide a brief review of the literature regarding the impact of such policies on the vaccination rates among health care workers and their attitudes toward mandated influenza vaccination, and we review key Canadian legal cases.

\section{Condition-of-service vaccination policies and rates of vaccination}

Policies requiring vaccination against influenza as a condition of service were first introduced in Ontario long-term care facilities in 1998: unvaccinated employees were required to take antiviral prophylaxis or remain off work during influenza outbreaks in their facilities ("may not work during facility outbreak" policies). Such policies were extended to acute care hospitals in Ontario in

2000 and have since been adopted by health care facilities in other jurisdictions across Canada.

More recently, an increasing number of acute care hospitals in the United States have implemented policies requiring influenza vaccination as a condition of service. Generally, these policies either require vaccination as a condition of employment (vaccination-required policies) or offer workers the choice of either being vaccinated or wearing a mask during periods of influenza activity (vaccinate-or-mask policies). Such policies typically include students, volunteers and contractors as well as employees.

In Canada, as of May 2014, at least one nursing home has a vaccination-required policy. All health authorities in British Columbia and one in New Brunswick and 13 hospitals in Ontario have recently implemented vaccinate-or-mask policies.

Table 1 summarizes the available data about the different types of condition-of-service policies and the associated vaccination rates among health care workers.

\section{Health care workers' attitudes toward condition-of-service vaccination policies}

Health care agencies may be reluctant to implement condition-of-service policies because of a concern about causing discontent among employees. However, among North American surveys each including more than 200 respondents published since $2010,57 \%-85 \%$ of health care workers supported or strongly supported influenza vaccination as a condition of service. ${ }^{30-36}$ Support for condition-of-service policies is associated with increased knowledge of influenza vaccine science, ${ }^{30,36,37}$ a lengthier career in health care ${ }^{31,32}$ and more exposure to seriously ill patients with influenza $\mathrm{z}^{31,38}$ - emphasizing that education is a critically important component for gaining employee acceptance when condition-of-service policies are introduced. Health care workers who work in a setting with an immunization mandate are also more likely to support such a mandate. ${ }^{36,39}$ Perhaps surprisingly, in some surveys, a significant minority of 
unvaccinated workers have reported being in favour of condition-of-service policies. ${ }^{36,40,41}$

\section{Condition-of-service vaccination policies and the law}

Although there may be growing support for condition-of-service policies among health care workers, this does not make such policies legal. In Canada, policies requiring influenza vaccination as a condition of service must comply with employment law, human rights codes and the Canadian Charter of Rights and Freedoms (Table 2).

\section{Employment law}

To comply with employment law, a policy that applies to unionized employees must be consistent with the collective agreements between employers and labour unions. Policies must be a reasonable exercise of management rights, which, among other things, requires the policy to be connected to the employer's legitimate business interests. In this case, the relevant business interest lies in protecting patient health and safety.

Most cases considering the lawfulness of condition-of-service policies for influenza vaccination are grievances by unionized employees arguing that these policies violate the collective agreement because they violate the employee's bodily integrity, autonomy and privacy. In contrast, health care employers have argued that these policies are substantially connected to their interest in protecting patients from a real and significant safety risk $^{44,51}$ and that they provide a "choice with consequences": an employee can choose not to be vacci- nated at the risk of being off work (either temporarily or permanently) or being required to wear a mask. The arbitrators who have considered these grievances have generally taken a balancing of interests approach, ${ }^{44}$ weighing the individual rights of employees against the consequences for patients.

Based on the evidence of effectiveness of the vaccination of health care workers, all arbitrators but one have concluded that policies prohibiting health care workers from working during facility outbreaks are consistent with collective agreements, given the weight of evidence that such policies are connected with the health care organization's interest in patient safety. ${ }^{42-45,48}$ These arbitrators have reasoned that such policies are not disciplinary in nature and that they are consistent with the fundamental obligations of the employee to safeguard the health and safety of patients. In the single contradictory decision, in 2002, the arbitrator concluded that an unpaidleave policy was unreasonable because it constituted mandatory medical treatment and removed the employee's choice. ${ }^{46}$ However, in two other cases concerning vaccination-required policies, arbitrators have upheld the employers' decisions to dismiss an unvaccinated employee. In the case of the Kotsopoulos grievance, ${ }^{48}$ the arbitrator concluded that the decision to dismiss a paramedic who declined vaccination, which was then required by the Ontario Ambulance Act, was consistent with the collective agreement. In the case of Barkley, an arbitrator upheld the decision to dismiss a nonunionized health care worker when she refused to be vaccinated. ${ }^{49}$

In the recent decision involving British Columbia's Health Sciences Association, the arbitrator

Table 1: Condition-of-service policies in health care agencies and vaccination rates among health care workers

Policy

May not work during facility outbreaks*

Vaccinate or mask $\dagger$
Impact on vaccination rates

- Initial implementation in Ontario in 1998/99 increased vaccination rates in long-term care facilities from $38 \%$ to more than $90 \% .{ }^{5}$ However, vaccination rates subsequently decreased to less than $60 \% .^{5}$

- Similar policies implemented in Ontario acute care hospitals and in long-term care facilities in other provinces were not associated with such substantial increases in vaccination rates.

- Significant increase in vaccination rates, achieving rates between $53 \%$ and $95 \% .{ }^{11-18}$ Higher rates were achieved in centres with higher preimplementation rates, and perhaps with more stringent enforcement and greater consequences for nonadherence.

- Experiences from 13 Canadian acute care hospitals and 2 health authorities or groups of health authorities suggest that implementation is associated with increases in vaccination rates of $17 \%-35 \%$ in the first year.§

Vaccination required $\neq$

- In the United States, such policies have increased vaccination rates to $>95 \% .{ }^{17-29}$

- One Ontario long-term care facility has had a successful policy for more than 5 years.

* "May not work during facility outbreak" policies require workers who are not vaccinated against influenza to not work in a health care facility during a declared facility outbreak of influenza.

tVaccinate-or-mask policies require unvaccinated health care workers to wear a mask while in areas where patient care is provided or patients may be present during the winter or influenza season.

$\neq$ Vaccination-required policies require that workers be vaccinated against influenza annually if they wish to work for the facility or agency.

§Personal communications: Dr. Gordon Dow (Moncton Hospital), 2013; Dr. Bonnie Henry (BC Centre for Disease Control), 2014; Dr. Kevin Katz (North York General Hospital), 2014. 
ruled that a vaccinate-or-mask policy was consistent with the collective agreement. In finding the policy to be reasonable, the arbitrator noted that the evidence showed that the policy was the least intrusive policy needed to increase patient safety and that situations in which wearing an opaque mask would impede the ability to perform the jobs (e.g., some speech language therapy) would be individually accommodated. ${ }^{47}$

\section{Provincial human rights codes}

Condition-of-service policies must also comply with provincial human rights codes, which prohibit discrimination in employment based on disability or creed (among other grounds). Canadian courts have endorsed a multidimensional definition of "disability," which may be real or perceived and which emphasizes human dignity, respect and the right to equality. ${ }^{52}$ Although there has been no case to date, a court might conclude that a condition-of-service vaccination policy must exempt individuals who have a medical contraindication to influenza vaccination.

With respect to "creed," this is defined in Ontario as "a set of sincerely held religious beliefs or practices which need not be based on the edicts of an established church or particular denomination." ${ }_{53}$ The Human Rights Tribunal of Ontario, which enforces The Ontario Human Rights Code, recently considered a case in which a paramedic argued that his employer discriminated against him by refusing to schedule him until he was vaccinated. ${ }^{50}$ The tribunal concluded that the employee's refusal to receive the influenza vaccination was based not on creed but rather on a general objection to immunization. Although the applicant in that case did not satisfy the legal standard, it is likely that condition-of-service vaccination policies must permit exemptions that accommodate religious beliefs and practices.

\section{The Canadian Charter of Rights and Freedoms}

Condition-of-service policies may also be subject to the Canadian Charter of Human Rights and Freedoms. If government conduct (e.g., provincial legislation or a medical officer of health) violates an individual's charter-protected rights, a court can declare it to be unconstitutional. The charter would thus apply to a provincial law mandating influenza vaccination of health care workers. The charter might apply to a policy introduced by a health care facility, but only if that policy is considered to be the implementation of a broader governmental policy. ${ }^{10,54,55}$ Although some arbitrators have applied the charter to hospital facility policies, ${ }^{42,46}$ others have refused, ${ }^{45}$ and one considered charter issues but did not rule on whether the charter applied. ${ }^{47}$

In cases to date, it has been argued that two sections of the charter may be violated by conditionof-service vaccination policies: the right to liberty and security of the person (section 7), and the right to freedom of expression (section 2b). The right to security of the person has been interpreted by courts as protecting an individual's physical integrity and a person's right to make choices concerning his or her own body. ${ }^{56,57}$ The right to liberty, which has been considered less frequently in the

Table 2: Canadian legal cases related to condition-of-service policies for influenza vaccination of health care workers

\begin{tabular}{|c|c|c|c|}
\hline \multirow{2}{*}{$\begin{array}{l}\text { Condition-of-service } \\
\text { policy }\end{array}$} & \multicolumn{3}{|c|}{ Area of law } \\
\hline & Employment law & Human rights codes & Canadian Charter of Rights and Freedoms \\
\hline $\begin{array}{l}\text { May not work } \\
\text { during facility } \\
\text { outbreak* }\end{array}$ & $\begin{array}{l}\text { In all but one case, } \\
\text { policies are lawful }\end{array}$ & No relevant cases & $\begin{array}{l}\text { Where applicable§, cases have been divided on } \\
\text { whether such policies violate the right to liberty and } \\
\text { security of person (section 7) }\end{array}$ \\
\hline Vaccinate or mask $\dagger$ & Policies are lawful & $\begin{array}{l}\text { Lawful if the policy provides } \\
\text { exemptions for creed and } \\
\text { disability }\end{array}$ & $\begin{array}{l}\text { Where applicable§: } \\
\text { - No violation of the right to liberty and security } \\
\text { (section 7) } \\
\text { - Possible violation of the right to freedom of } \\
\text { expression (section } 2 \text { b), which would be justified } \\
\text { by section } 19\end{array}$ \\
\hline $\begin{array}{l}\text { Vaccination } \\
\text { required } \neq\end{array}$ & Policies are lawful & $\begin{array}{l}\text { Lawful if the policy provides } \\
\text { exemptions for creed (no } \\
\text { cases related to disability) }\end{array}$ & No relevant cases \\
\hline \multicolumn{4}{|c|}{$\begin{array}{l}\text { *"May not work during facility outbreak" policies require workers who are not vaccinated against influenza to not work in a health care facility during a declared } \\
\text { facility outbreak of influenza (decisions } \\
\text { tVaccinate-or-mask policies require unvaccinated health care workers to wear a mask while in areas where patient care is provided or patients may be present } \\
\text { during the winter or influenza season (single decision }{ }^{47} \text { ). } \\
\text { tVaccination-required policies require that workers be vaccinated against influenza annually if they wish to work for the facility or agency }\left(3 \mathrm{decisions}{ }^{48-50} \text { ). }\right. \\
\text { \$The charter applies to government policies. Whether the charter applies to health care facility and/or agency policies is a complex legal question and is addressed } \\
\text { in the main text. } \\
\text { qSection } 1 \text { of the charter specifies that charter rights may be limited if it can be shown that the breach is reasonable and demonstrably justified. }\end{array}$} \\
\hline
\end{tabular}


health care context, has been interpreted as including the power to make personal and autonomous decisions with respect to one's health care. ${ }^{58}$ The right to freedom of expression has been interpreted to include the right "to say nothing or not to say certain things." ${ }^{99}$ These individual rights are not unlimited. The rights to liberty and security of the person can be breached if to do so is consistent with the "principles of fundamental justice." Both of these rights and the right to freedom of expression may also be breached where it can be shown that the breach is reasonable and justified in accordance with section 1 of the charter.

With respect to the rights to liberty and security, vaccinate-or-mask policies have been found not to violate liberty or security rights, because the vaccine is not mandatory and masks are insufficiently invasive to violate these rights. ${ }^{47}$ Decisions to date are divided on whether policies prohibiting health care workers from working during facility outbreaks violate the liberty and security interests of health care workers. The principal difference between these decisions is how the arbitrator perceived the severity of the policy's consequences and whether the health care worker can be seen as having a true choice to be vaccinated. Thus, in the case of St. Peter's Health System, the arbitrator concluded that the policy violated the employees' security and liberty rights ${ }^{46}$ this arbitrator did not go on to determine whether the violation was consistent with the principles of fundamental justice or was reasonable and justified. By contrast, in the 2006 decision involving the Health Employers Association of $\mathrm{BC}$, the arbitrator concluded that the health care worker's right to liberty and security were not engaged because the imposed economic consequences were not sufficiently severe as to effectively deny an individual choice over her body. ${ }^{42}$

Vaccination-required policies are, of course, associated with much more severe economic consequences than policies prohibiting health care workers from working during facility outbreaks. Although no arbitrator or court has considered whether such policies violate the charter, they may be seen as leaving the employee with no choice but to be vaccinated. ${ }^{43}$ However, the Supreme Court of Canada has consistently refused to recognize that the charter protects economic rights, such as the right to work, which may present an important obstacle to this argument. ${ }^{60}$

With respect to freedom of expression, BC's Health Sciences Association argued that compelling an unvaccinated worker to wear a mask is a form of "forced expression" because it may reveal to others that he or she chooses not to be vaccinated. The arbitrator in this case recognized that this might be the case but ruled that the employer had shown that the policy was a reasonable and justifiable limit on employee rights. ${ }^{47}$

It is important to note that, if a condition-ofservice policy is judged to have breached charter rights, the details of the policy will be critical in determining whether the breach is justified. To be justifiable, the specific policy must be tailored to its stated objective and must impair the rights of individuals as little as possible. Thus, employers should carefully consider which groups of employees pose a risk to patients if they remain unvaccinated, when influenza activity is sufficient to warrant work exclusion, whether alternatives have truly been exhausted, what is the appropriate consequence of refusing to be vaccinated, and whether this consequence is fairly applied. ${ }^{45,47}$

\section{Conclusion}

Vaccinate-or-mask policies for influenza vaccination in health care organizations result in substantial increases in the vaccination rates among health care workers, are supported by most health care workers and, based on decisions to date, are likely to be found to be in compliance with Canadian law. Although vaccination-required policies have been upheld by arbitrators, employers who opt for more intrusive policies should carefully consider whether the details of such a policy maximize patient safety while impairing the charter rights of health care workers as little as possible. Physicians and employers should work together to find the best means to improve vaccination rates and protect both patients and providers from influenza.

\section{References}

1. National Advisory Committee on Immunization. Statement on seasonal influenza vaccine for 2013-2014. Can Commun Dis Rep 2013;39:1-37. Available: www.phac-aspc.gc.ca/publicat/ccdr-rmtc /13vol39/acs-dcc-4/index-eng.php\#ackn (accessed 2013 Dec. 15).

2. Prevention and control of influenza with vaccines: interim recommendations of the Advisory Committee on Immunization Practices (ACIP), 2013. MMWR Morb Mortal Wkly Rep 2013;62: 356.

3. Flegel K. Health care workers must protect patients from influenza by taking the annual vaccine. CMAJ 2012;184:1873.

4. Gardam M, Lemieux C. Mandatory influenza vaccination? First we need a better vaccine. CMAJ 2013;185:639-40 1.

5. Ontario Respiratory Virus Bulletin. Toronto (ON): Public Health Ontario; 2014. Available: www.publichealthontario.ca/en/Data AndAnalytics//Documents/Ontario_Respiratory_Virus_Bulletin -Week112014.pdf (accessed 2014 May 3).

6. Alberta respiratory virus surveillance report: update for flu weeks 31-34: (Jul. 28-Aug. 24, 2013). Calgary (AB): Alberta Health Services; 2013. Available: www.albertahealthservices.ca/poph/hipoph-surv-resp-virus-2013-08-29.pdf (accessed 2013 Oct. 9).

7. Bryce E, Embree J, Evans G, et al. AMMI Canada position paper: 2012 mandatory influenza immunization of health care workers. Can J Infect Dis Med Microbiol 2012;23:e93-e95.

8. Influenza vaccination honor roll. St. Paul (MN): Immunization Action Coalition. Available: www.immunize.org/honor-roll /influenza-mandates/ (accessed 2014 Feb. 26).

9. Ottenberg AL, Wu JT, Poland GA, et al. Vaccinating health care workers against influenza: the ethical and legal rationale for a mandate. Am J Public Health 2011;101:212-6.

10. Rodal R, Ries NM, Wilson K. Influenza vaccination for health care workers: towards a workable and effective standard. Health Law J 2009;17:297-337. 
11. Paris B, Arahood T, Asche C, et al. Voluntary reporting of health care personnel seasonal influenza vaccination rates and the impact of universal policies in Illinois hospitals. Vaccine 2013;31:514-7.

12. Modak RM, Parris SM, Dilisi JP, et al. Increasing influenza vaccination rates among hospital employees without a mandatory policy. Infect Control Hosp Epidemiol 2012;33:1288-9.

13. Wicker S. Unvaccinated health care workers must wear masks during flu season-a possibility to improve influenza vaccination rates? Vaccine 2009;27:2631-2.

14. Perlin JB, Septimus EJ, Cormier SB, et al. Developing a program to increase seasonal influenza vaccination of healthcare workers: lessons from a system of community hospitals. $J$ Healthc Qual 2013;35:5-15.

15. Esolen LM, Kilheeney KL, Merkle RE, et al. An alternate approach to improving healthcare worker influenza vaccination rates. Infect Control Hosp Epidemiol 2011;32:703-5.

16. Cadena J, Prigmore T, Bowling J, et al. Improving influenza vaccination of healthcare workers by means of quality improvement tools. Infect Control Hosp Epidemiol 2011;32:616-8.

17. Miller BL, Ahmed F, Lindley MC, et al. Increases in vaccination coverage of healthcare personnel following institutional requirements for influenza vaccination: a national survey of U.S. hospitals. Vaccine 2011;29:9398-403.

18. Helms C, Polgreen P, Polgreen L, et al. Voluntary reporting of employee influenza vaccination rates by acute care hospitals in Iowa: the impact of a four- year provider-based statewide performance improvement project. Vaccine 2011;29:3483-8.

19. Babcock HM, Gemeinhart N, Jones M, et al. Mandatory influenza vaccination of health care workers: translating policy to practice. Clin Infect Dis 2010;50:459-64.

20. Parada J, Chauhan D, Gaughan B, et al. Duh, why didn't we do this sooner?! Three year experience with mandatory seasonal influenza immunization for all personnel in a university medical center [poster]. IDWeek meeting; 2012 Oct 20-23; San Diego (CA). Available: https://idsa.confex.com/idsa/2012/webprogram /Paper37822.html

21. Rakita RM, Hagar BA, Crome P, et al. Mandatory influenza vaccination of healthcare workers: a 5-year study. Infect Control Hosp Epidemiol 2010;31:881-8.

22. Karanfil LV, Bahner J, Hovatter J, et al. Championing patient safety through mandatory influenza vaccination for all healthcare personnel and affiliated physicians. Infect Control Hosp Epidemiol 2011;32:375-9.

23. Smith DR. Mandatory influenza vaccine for health care workers: 2012 results [letter]. WMJ 2013;112:6

24. McFadden MM, Sadler A. Implementation of a mandatory influenza vaccination program in an academic medical center [presentation]. The 38th Annual Educational Conference and International Meeting of the Association for Professionals in Infection Control and Epidemiology; 2011 June 26-29; Baltimore (MD).

25. Doby D, Stockman C, Petersen S, et al. Mandatory employee vaccination policy with termination for non-compliance increases vaccine coverage in a large, not-for-profit health system [poster]. IDWeek meeting; 2012 Oct 20-23; San Diego (CA). Available: https://idsa.confex.com/idsa/2012/webprogram/Paper35063.html.

26. Duncan R, Kelly JE, Willey S, et al. An 11th hour mandatory influenza healthcare worker vaccination vs. mask policy [abstract]. Proceedings of the 2011 Annual Meeting of the Infectious Diseases Society of America; 2011 Oct 20-23. Available: https://idsa.confex.com/idsa/2011/webprogram/Paper32151.htm (accessed 2013 Aug. 6).

27. Gaughan B A. The successful implementation of mandatory seasonal influenza vaccination for health care workers at an academic medical center. Am J Infect Control 2010:38(5):E51.

28. Currie D, Malow J. Successful implementation of a mandatory influenza vaccination program across a 12 hospital system. Am J Infect Control 2012;40:e98-9.

29. Huynh S, Poduska P, Mallozzi T, et al. Mandatory influenza vaccination of health care workers: a first-year success implementation by a community health care system. Am J Infect Control 2012;40:771-3

30. Banach DB, Zhang C, Factor SH, et al. Support for mandatory health care worker influenza vaccination among allied health professionals, technical staff, and medical students. Am J Infect Control 2013;41:354-6.

31. deSante JE, Caplan A, Shofer F, et al. Physician attitudes towards influenza immunization and vaccine mandates. Vaccine 2010;28:2517-21.

32. Douville LE, Myers A, Jackson MA, et al. Health care worker knowledge, attitudes, and beliefs regarding mandatory influenza vaccination. Arch Pediatr Adolesc Med 2010;164:33-7.
33. Feemster KA, Prasad P, Smith MJ, et al. Employee designation and health care worker support of an influenza vaccine mandate at a large pediatric tertiary care hospital. Vaccine 2011;29: 1762-9.

34. Hakim H, Gaur AH, McCullers JA. Motivating factors for high rates of influenza vaccination among healthcare workers. Vaccine 2011;29:5963-9.

35. Kent JN, Lea CS, Fang X, et al. Seasonal influenza vaccination coverage among local health department personnel in North Carolina, 2007-2008. Am J Prev Med 2010;39:74-7.

36. Maurer J, Harris KM, Black CL, et al. Support for seasonal influenza vaccination requirements among US health care personnel. Infect Control Hosp Epidemiol 2012;33:213-21.

37. Seale H, Leask J, Macintyre CR. Awareness, attitudes and behavior of hospital health care workers towards a mandatory vaccination directive: two years on. Vaccine 2011;29:3734-7.

38. Polgreen PM, Septimus E, Talbot TR, et al. Results of a national survey of infectious diseases specialists regarding influenza vaccination programs for health care workers. Infect Control Hosp Epidemiol 2010;31:1063-5.

39. Bunko Patterson A, Sylvester T, Stewart J, et al. Attitudes toward mandated influenza vaccinations among healthcare workers and predictors of healthcare worker support of mandatory influenza vaccination - Maricopa County, Arizona [poster]. IDWeek meeting; 2012 Oct 20-23; San Diego (CA).

40. Looijmans-van den Akker I, Marsaoui B, Hak E, et al. Beliefs on mandatory influenza vaccination of health care workers in nursing homes: a questionnaire study from the Netherlands. $J$ Am Geriatr Soc 2009;57:2253-6.

41. Lester RT, McGeer A, Tomlinson G, et al. Use of, effectiveness of, and attitudes regarding influenza vaccine among house staff. Infect Control Hosp Epidemiol 2003;24:839-44.

42. Health Employers Assn. of British Columbia v. British Columbia Nurses' Union [2006], 155 L.A.C. (4th) 252.

43. Re Trillium Ridge Retirement Home and S.E.I.I. Loc. 183 , [1998] O.L.A.A. No. 1046.

44. Re Chinook Health Region and U.N.A. Loc. 120 (2002), 113 L.A.C. (4th) 289.

45. Re Carewest v. Alberta (2001) 104 L.A.C. (4th) 240. Carewest v Alberta Union of Provincial Employees (Nasr Grievance) (2001), 104 L.A.C. (4th) 240, [2001] A.G.A.A. No. 76.

46. St. Peter's Health System v. Canada Union of Public Employees, Local 778 (Flu vaccination grievance) [2002] 106 L.A.C. (4th) 170.

47. Health Employers Assn. of British Columbia v. the Health Sciences Assn (2013) 237 L.A.C. (4th) 1, [2013] B.C.C.A.A.A. No. 138

48. North Bay General Hospital and C.U.P.E., Loc. 139 (Kotsopoulos greivance) (2003) 122 L.A.C. (4th) 366.

49. Barkley v. Mohawk Council of Akwesasne, [2000] C.L.A.D. No. 553 (QL) (federal).

50. Ataellahi v. Lambton County (EMS), 2011 HRTO 1758.

51. Re Lumber \& Sawmill Workers' Union, Local 2537 and KVP Co. Ltd. 16 L.A.C. 73

52. Quebec (Commission des droits de la personne et des droits de la jeunesse) v. Montreal (city); Quebec (Commission des droits de la personne et des droits de la jeunesse) v. Boisbriand (city), 2000 SCC 27.

53. Human Rights Code, R.S.O. 1990, C. H-19. Huang v. 1233065 Ontario Inc. (No. 2), 2006 HRTO 1.

54. Stoffman v. Vancouver General Hospital, [1990] 3 SCR 483.

55. Eldridge v. British Columbia (A.G.), [1997] 3 S.C.R. 624.

56. R. v. Morgentaler [1988] 1 S.C.R. 30.

57. Rodriguez v. British Columbia (Attorney General), [1993] 3 S.C.R. 519

58. Fleming v. Reid (1991), 4 O.R. (3d) 74.

59. Slaight Communications v. Davidson, [1989] S.C.J No 45 at para 925.

60. Hogg PW. Constitutional law of Canada: 2003 student edition. Toronto (ON): Thompson/Carswell; 2003:983.

Affiliations: Faculty of Common Law (Gruben), University of Ottawa, Ottawa, Ont.; Department of Internal Medicine (Siemieniuk), University of Toronto; Department of Laboratory Medicine and Pathobiology and the Dalla Lana School of Public Health (McGeer), University of Toronto, Toronto, Ont.

Contributions: Allison McGeer and Vanessa Gruben conceived the idea for this commentary. Reed Siemieniuk conducted the literature reviews. All authors contributed to the drafting and revising of the manuscript, and approved the final version submitted for publication. 